Impact Factor: 4.845(SJIF) Research Journal Of English (RJOE) Vol-5, Issue-2, 2020

www.rjoe.org.in An International Peer-Reviewed English Journal

ISSN: 2456-2696

Indexed in: International Citation Indexing (ICI), International Scientific Indexing (ISI), Directory of Research Journal Indexing (DRJI) Google Scholar \& Cosmos.

\title{
ECOLOGICAL IMPERIALISM AND JOSEPH CONRAD'S HEART OF DARKNESS
}

\author{
Dr.Gazala Gayas \\ Associate Prof. in English \\ A.S .College Cluster University Srinagar, India
}

\begin{abstract}
Ecological Imperialism is the devastation and adverse effects of Imperialism on colonized ecologies. The paper aims at discussing the adverse effects of European Imperialism on African Ecologies as portrayed by in Conrad his novel Heart of Darkness. Ecological Imperialism is a sociological phenomenon dealing with environmentally discriminatory treatment of socially marginalized or economically disadvantaged people. In Heart of Darkness, Conrad exposes European Colonizers. In order to earn more they not only maltreat native Africans but they harm their Nature also. They kill their animals; destroy their jungles just to quench their greed. In Heart of Darkness, Conrad (1899) sees Africa rich in material resources but inhabited by species of savaged humanity a little above animals with neither culture nor intelligible communication which justified the colonial exploitation of the region and the disruption of their culture and nature.
\end{abstract}

Keywords: Ecological Imperialism, Ecology, Imperialism, Environment, Marginalization, Colonization, Europe, Colonizers, Colonized.

Ecological Imperialism concerns the devastating and adverse effects of imperialism on the colonized ecologies apart from the devastating effects on colonized communities. The tem'Ecological Imperialism' was coined by Alfred Crosby. Deane Curtin, an American Environmentalist defines it as, "the connection, in theory and practice of race, and the environment so that the oppression of one is connected to and supported by, the oppression of the other" (4). In short it is a sociological phenomenon dealing with environmentally discriminatory treatment of socially marginalized or economically disadvantaged people.

The story of Heart of Darkness opens with an image of London as it was in Conrad's day- the wealthiest and the most powerful city in the world. Conrad addresses the most important economic, political and social issue of the era; Imperialism. England had begun extending its domain through Imperialism, an activity that Belgium's King Leopold was thoroughly exploiting Africa under guise of enlightenment and international trade. Joseph Conrad's Heart of Darkness tells the journey of Marlow through the African 
Impact Factor: 4.845(SJIF) Research Journal Of English (RJOE) Vol-5, Issue-2, 2020

www.rioe.org.in An International Peer-Reviewed English Journal

ISSN: 2456-2696

Indexed in: International Citation Indexing (ICI), International Scientific Indexing (ISI), Directory of Research Journal Indexing (DRJI) Google Scholar \& Cosmos.

jungles. Conrad himself observed through his own experience in Africa and on river Congo how Europeans exploited and Imperialize not only African natives, but their natural resources also. Through Marlow's narrative the readers were made aware of the horrific aspects of Imperialism.

In Heart of Darkness the narrator Marlow is not able to define the native Africans. Marlow understands that they suffer under the control of Europeans. Even Marlow is aware of the fact that in order to earn more the Europeans not only maltreat natives, but they harm their Nature also. They destroy the jungles, and kill the animals, just to quench their greed. Marlow himself narrates that in Africa he has seen, "devil of violence, devil of greed, and devil of hot desire"(17).

The violence is indispensable part of European Imperialism and it is constantly present in the novel. Marlow tells that a native thought to cause fire, has been beaten harshly. The novel reveals the violence and brutality through the character of Kurtz, "Kurtz has a lots of abilities from art to music, although he is a cruel man(81). Kurtz is the most influential medium of European Imperialism and Colonization. He is sure that, the ivory trade which he is responsible for is more productive than any other region. De Loughrey and Hanley in"Introduction: Towards an Aesthetics of Earth" says:

If there is anything that radically distinguishes the imagination of anti-Imperialism. It is primacy of the geographical in it. Imperialism after all is an act of geographical violence through which virtually every space in the world is explored, charted, and finally brought under control. For the native, the history of colonial servitude is inaugurated by the loss of locality to the outsider, its geographical identity must thereafter be searched for and somehow restored. (3)

His methods are brutal. His hut is surrounded by skulls of men who do not obey him. He deliberately turns the faces of these skulls to the house since he wants his power to be recognized by the natives. Kurtz imposes Imperialism on natives of Africa and its lands to gain more wealth through ivory trade, timber and human resources, but his avarice leads his death. As Edward Said puts, " the whole point of what Kurtz and Marlow talk about is in fact imperial mastery, white European over black Africans, and their ivory, civilization over primitive dark continent(20).

In Heart of Darkness, Conrad (1899) sees an Africa rich in material resources but inhabited by species of savaged humanity a little above animals with neither culture nor intelligible communication which justified the colonial exploitation of the region and the disruption of their culture. As Achebe puts it: Heart of Darkness projects the image of Africa as "the other world," the antithesis 
Impact Factor: 4.845(SJIF) Research Journal Of English (RJOE) Vol-5, Issue-2, 2020

www.rioe.org.in An International Peer-Reviewed English Journal

ISSN: 2456-2696

Indexed in: International Citation Indexing (ICI), International Scientific Indexing (ISI), Directory of Research Journal Indexing (DRJI) Google Scholar \& Cosmos.

of Europe and therefore of civilization, a place where man's vaunted intelligence and refinement are finally mocked by triumphant bestiality. The book opens on he river Thames, tranquil, resting, peacefully "at the decline of day after ages of good service done to the race that peopled its banks." But the actual story world. (3).

Therefore, Kurtz represents all the men that:"fall" apart from what Conrad calls "the toil of life" from which men derive their vital energy, he stands for all those that commit the "sin" of being fascinated by the abomination of an egotistical, damming trip that carries them into the "barren darkness" of their individualities. Indeed, after the end of Kurtz's voyage there appears the sham, selfish, "fallen" man who possesses only a factitious, rhetorical power to hide his hollowness:" ...A voice: a voice: deep to the very last. My Intended...my station...my career.., my ideas... utterances of elevated sentiments... The shade of the original Kurtz frequented the bedside of the hollow sham..." (98).

In Heart of Darkness, the 'darkness' symbolizes and represents various parts of reality, human nature, and the corruption of decency when faced with insurmountable obstacles. Kurtz's painting is perhaps the most extensive symbol in Heart of darkness. Kurtz's painting is a symbol of the whole prevented enterprise (5). The Congo river is also a very important symbol in Heart of Darkness. It river resembles a snake, and the snake symbolizes the idea of temptation and evil. There, is another example to reveal how the European mind puts the natural world and its inhabitants into the same category of its ultimate Other. Evidently both the human inhabitants and the elephants are alienated as the 'other' in an undifferentiated way by the European traders and thus emptied of their intrinsic value so that the extermination of the entire elephant population for more ivory can be justified. The managers and agents of the company are so obsessed with obtaining ivory that they forget about their morals. So, the ivory is a clear symbol of greed in this novel (9). Jesse Hosier in his essay "What is Ecological Imperialism" states that:

Ecological Imperialism is a policy of extending a countries power/ influence through colonization, use of military force or other means. Ecological Imperialism is where plants, animals and diseases are introduced (can be accidental or deliberate), the introduction of these things leads to shift in the ecology of colonized area, which in turn, makes it extremely easy for another country to take control of the area.(1)

The Eldorado Exploring Expedition, run by the manager's uncle, is a groupof the whites, search for something that cannot be attained. This fictional expedition is based on an actual one: The Katanga Expedition. The fact that the manager's uncle leads the expedition suggests that it is another example of white trades scrambling for riches in Congo. Marlow dismisses them as "buccaneers", who do not even make pretence of coming to Africa for anything other than treasure. 
Impact Factor: 4.845(SJIF) Research Journal Of English (RJOE) Vol-5, Issue-2, 2020

www.rjoe.org.in An International Peer-Reviewed English Journal

ISSN: 2456-2696

Indexed in: International Citation Indexing (ICI), International Scientific Indexing (ISI), Directory of Research Journal Indexing (DRJI) Google Scholar \& Cosmos.

The imposition of colonialism on Africa was formalized by the coming together of the empire-building European powers; Britain, France, Germany, Portugal and Spain, to divide Africa up among themselves at the Berlin conference of 1884-1885. This event, commonly called 'the partition of Africa' was originally conceived as part of a strategy to co-ordinate the ongoing scramble among the major European powers for what was then regarded as the 'Dark Continent'. Ironically, the attempt to mediate the conflicting claims and counter claims over the portions of Africa that each major European power wanted for exclusive commercial and administrative control quickly led to one of the most catastrophic events in the continent's history: termination of autonomy or self-rule, and transformation of traditional village life enjoyed by African people all over the continent until then.

The discovery of gold and diamond collection and the availability of cheap or forced 'free' labour, help to explain the motivation of the Europeans. Colonialist's and colonized show glaring differences of poverty and penury juxtaposed against the organised and affluent environment. The impacts of colonialism and its legacies cannot be severed from the environment since colonialism usually introduces environmental racism. Bunyan Bryant validates connections existing among imperialism, colonialism and racism in his definition of environmental racism. According him:

It [environmental racism] is an extension of racism. It refers to those institutional rules, regulations, and policies government or corporate decisions that deliberately target certain communities for least desirable land uses, resulting in the disproportionate exposure of toxic and hazardous waste on communities based upon certain prescribed biological characteristics. (27)

Apart from environmental racism, there is exploitation of non-human resources which were used in enriching the colonialist's mother countries. The years of colonialism saw an export of Africa's resources and raw materials for the development of Europe.Ecological imperialism emptied nature of its intrinsic value and turned it into a wholesale commodity. The impact of enforced land conversion to production value, or for capital resource, regardless of its suitability to the local ecosystems, in the indigenous environments, for instance, resulted in such damage that it included not only the nonhuman resources but also the indigenous peoples themselves.

But worse than that the colonial imperialist expansion spread the culture of ecological imperialism among the colonized peoples around the world. Mastery of nature is therefore closely linked with racist ideologies, Eurocentric colonialist discourses, and imperialist power politics. Thus the colonialist implication of this depiction is of course to 
Impact Factor: 4.845(SJIF) Research Journal Of English (RJOE) Vol-5, Issue-2, 2020

www.rioe.org.in An International Peer-Reviewed English Journal

ISSN: 2456-2696

Indexed in: International Citation Indexing (ICI), International Scientific Indexing (ISI), Directory of Research Journal Indexing (DRJI) Google Scholar \& Cosmos.

show that the Africans are unworthy of the riches of their own land. The underlying implications of such negative representations then clarify the rationale behind it, therefore, is interesting to see that the representations of the Africans and their land in terms of extreme racist distortion, both ecologically and culturally, actually serve to expose the hollowness of Western civilization's anthropocentric orientation in its absurd superiority complex to achieve mastery over the world.

\section{References:}

- Athol, Fugard. Sorrows and Rejoicing. South Africa: Samuel French. 2002. Print.

- Bennett, Andrew And Royle, Nicholas.ed.An Introduction to Literature, Criticism and Theory. Britain: Pearson/Longan, 2009. Print.

- Bryant, Bunyan. Introduction. Environmental Justice: Issues, Policies, and Solutions. Washington DC: Island Press. 1995. Print .

- Buell, Love. The Future of Environmental Criticism: Environmental Crisis and Literary Imagination. Oxford: Blackwell. 2005. Print.

- Caminero-Santangelo, Byron. and Myers, Gath. .Eds. Environment at the Margins Literary and Environmental Studies in Africa. Ohio University Press: Athens, US. 2011. Print.

- Conrad, Joseph. Heart of Darkness. New York: Global Classics, 1899. Print.

- Duerden, Dennis and Cosmo Pieterse. Ed. African Writers on African Writing. London: Heinemann, 1972. Print.

- Heise, U. Sense of Place and Sense of Planet: The Environmental Imagination of the Globe. Oxford: Oxford UP, 2008. Print.

- Huggan, G., and H. Tiffin. Postcolonial Ecocriticism: Literature, Animals, Environment. New York: Routledge, 2010. Print.

- Said, W. Edward Joseph Conrad and the Fiction of Autobiography. New York. A Columbia University Press, 2008. Print.

- Watt, Ian .Conrad in the Nineteenth Century. California. University Press of California: 1979. Print. 